\title{
Costs of road transport depending on the type of vehicles
}

\begin{abstract}
The article presents analysis of the road transport costs with regard to the types of vehicles. Discussed problem is important from the point of view of both the carrier and the company engaged in the organization of transport. The classification of costs in road transport significantly dependent on the types of used vehicle is presented. The factors affecting individual cost components with regard to the vehicles' value, the permissible total weight, type of engine and fuel are defined. Selected components of the costs are enhanced by original analytic formulas with given examples of their values under fixed parameters of realized transport service. The participation of selected components of costs in total costs of transport and their impact on the costs of transportation are investigated. Considerations are illustrated by numerical example which examined road transport carried out in relation Mszczonów (PL) - Hamburg (DE) by one driver. Examined variants are based on vehicles meeting Euro standard III, IV, V and VI. As it was shown, the most costeffective variant in discussed transport relation uses vehicles with highest emission standards.
\end{abstract}

Key words: transport costs, road transport costs, transport costs components, transport costs classification

\section{Introduction}

Selecting a vehicle to the transport task should take into account the task parameters and purpose of vehicles [12]. But today, in many cases the emission standard $[6,15]$ or other parameter like fuel tank capacity can be a decisive feature of the vehicle. These features of the vehicles may condition the possibility of transport task realization (like limiting entry to the low-emission zones), as well as significantly affect the cost.

Allocating vehicles to transport tasks is important both for the carrier and for senders and recipients [12]. The carrier is interested in maximizing the usage of existing transport potential and minimizing transport costs or the need to preserve consumptive or production features of goods shipped. In contrast senders and recipients, except preserving the proper features of shipped goods, require minimal transport time and its costs. In both cases the essential criterion for the selection of vehicles to transport tasks are the costs of transport $[4,8,21]$.

Concepts of investment expenditures, cost and expense presented in the literature are often used interchangeably what introduces a certain confusion and can lead to misleading conclusions. Expenditure, in general, is considered to be "reflection of necessary production factors, like means of production and human labour expressed in natural units used in the process of management. Expenditure means payments for the production factors or use of production factors, while cost is a reflection of inputs in the production process. At the same time costs can be dealt with under the Income Tax Act (as tax costs) [18] or in accordance with the Accounting Act (actual costs) [19].

The assessment of the decision variants about vehicles must primarily take into account the real costs of transport. The article presents considerations for the formation of these costs due to the types of vehicles. The particular attention is paid on environmental fees. On their level significantly affect the Euro standard met by the engine of vehicle.

\section{Types of costs in road transport}

The total costs generated by transport service provider are a sum of expenditures on realized services expressed as a cost value and settled at a certain time. Thus, the costs include fixed assets and current assets, the workload, as well as other expenses (taxes, interest, fees, rents etc.) justified from the point of view of business transport [3].

This means that the total costs of the company are composed of elements with different characteristics. This is why the classification of costs is performed by their systematic, extensive division into individual components according to established criteria (rules), and then combining these components in the respective groups (class) [3].

Costs incurred by the company to achieve sales of products or services, in accordance with the Accounting Act [19], are treated as operating expenses. In addition the other operating costs and financial costs are separated, which were omitted in the paper.

The following criteria for classification of operating expenses are used $[2,3]$ :

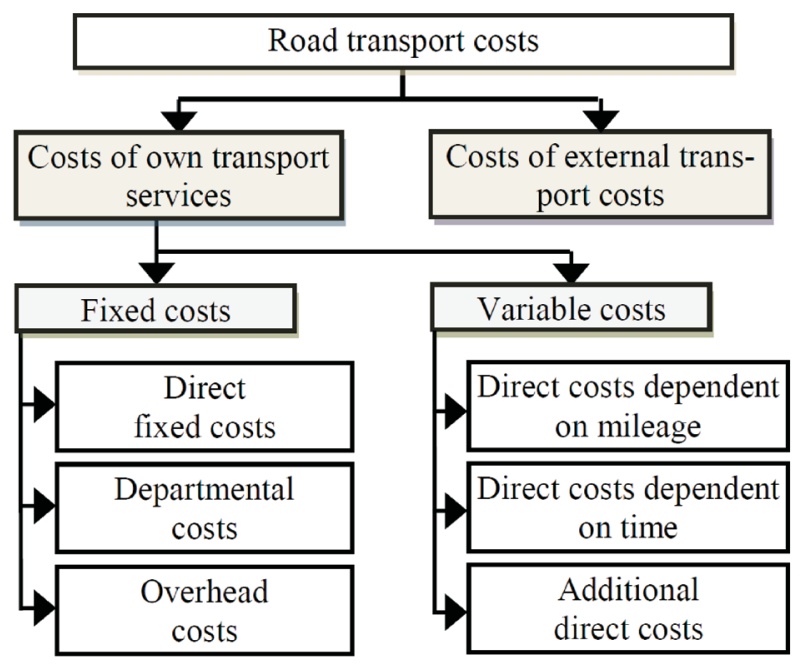

Fig. 1. General classification of costs in road transport 
- Types of activity,

- The complexity of costs,

- The type of costs,

- The variability of costs,

- The cost centres,

- The ratio of costs to the environment.

The publications relating to road transport most often use division of costs for indirect costs and direct fixed and variable costs . Thus, there are two criteria used simultaneously: variability and place of cost origin (Fig. 1).

Importantly, variable costs in road transport embrace also costs depend on mileage or working time, as well as additional variable costs resulting from the specific character of transport task that can't be directly related to the mileage or working time.

Types of costs in road transport in each group of fixed and variable costs are shown in Fig. 2.

\begin{tabular}{l} 
Overhead costs: \\
- wage of the company's board \\
- training and medical check of board members \\
- property maintenance costs \\
- energy costs. \\
\hline Departmental costs: \\
- administrative costs (including certificate, licenses) \\
- funding costs of departments equipment \\
- depreciation of fixed assets \\
- labour costs of departmental employees \\
- training and medical check of departmental staff. \\
\hline Direct fixed costs:: \\
- costs of periodic technical inspection of vehicles \\
- cost of vehicle insurance \\
- the cost of taxes on means of transport \\
- periodical duties for use of roads \\
- wear on the vehicle (depreciation) \\
- cost of vehicles financing (leasing and capital) \\
- labour costs of drivers \\
- costs of training and medical check of drivers. \\
\hline Direct variable costs dependent on the mileage: \\
- cost of fuel consumption \\
- tire wear costs \\
- costs of technical maintenance and repairs \\
- ecological fees. \\
Direct variable costs dependent on working time: \\
- remuneration components \\
- equipment rents. \\
- cargo insurance \\
- escorting cargo \\
- fees for permit for transportation. \\
- delegations drivers (diets accommodation costs) \\
- additives to wages and salaries (for on-call time for night work and \\
- \\
\end{tabular}

Fig. 2. Types of costs in the road transport

The following costs named in Fig. 2 can be considered as costs that are directly dependent on the type of vehicle :

- financing of vehicles,

- wear of the vehicles,

- periodic technical inspection of vehicles,

- vehicle insurance,
- taxes on means of transport,

- periodic charges for use of roads,

- fuel consumption,

- tire wear,

- technical services and repairs,

- environmental fees,

- one-time charges for the use of transport infrastructure.

Importantly these costs can be divided into dependent on the value of the vehicle (e.g. vehicle wear, financing, insurance) as well as those dependent on the type of engine, fuel, emission standard, number of axles and GVW (e.g. tolls on roads or taxes on means of transport).

\section{Fixed costs in road transport in correlation with used vehicles}

According to the previous considerations, the fixed costs depending on the type of vehicle include the costs of:

- financing of vehicles,

- wear of vehicles,

- periodic technical inspection of vehicles,

- vehicle insurance,

- taxes on means of transport,

- periodic charges for use of roads.

The first of these costs is dependent on the method of financing vehicles purchase and may include lease payments (in case of an operating lease) or the cost of freezing assets (in case of purchase of vehicles from own resources). In both cases these costs are directly related to the value of the vehicle and cost of capital (external or own). Moreover, in case of financing vehicles from own resources, one must take into account phasing out frozen assets through depreciation - which is unfortunately usually ignored. Therefore, these costs also result from the adopted method of depreciation.

With regard to above mentioned aspects, vehicle financing costs by own resources, under linear depreciation and calculated monthly are described as follows:

$$
\begin{gathered}
\mathrm{K}_{\mathrm{K}}^{\mathrm{Z}}(\mathrm{v})=\frac{\mathrm{W}_{\mathrm{P}}(\mathrm{v}) \cdot \alpha_{\mathrm{K}}}{12} \cdot \min \left\{\left[\frac{12}{\alpha_{\mathrm{A}}(\mathrm{v})}\right] ; \mathrm{N}^{\mathrm{E}}(\mathrm{v}) \cdot 12\right\} . \\
\cdot\left(1-\min \left\{\left[\frac{12}{\alpha_{\mathrm{A}}(\mathrm{v})}\right]-1 ; \mathrm{N}^{\mathrm{E}}(\mathrm{v}) \cdot 12-1\right\} \cdot \frac{\alpha_{\mathrm{A}}(\mathrm{v})}{2 \cdot 12}\right) . \\
\cdot \frac{\mathrm{t}_{\mathrm{PP}}^{\mathrm{O}}(\mathrm{v})}{\mathrm{N}^{\mathrm{E}}(\mathrm{v}) \cdot \mathrm{t}_{\mathrm{PP}}^{\mathrm{R}}(\mathrm{v})}
\end{gathered}
$$

where: $\mathrm{K}_{\mathrm{K}}^{\mathrm{Z}}(\mathrm{v})$ - cost of freezing assets invested to purchase vehicles per transport task performed by $\mathrm{v}$-th vehicle in PLN, $W_{p}(v)$ - the initial value (net value) of $v$-th vehicle in PLN, $\alpha_{k}-$ annual cost of freezing assets in \%/year, $\alpha_{A}(v)$ - annual depreciation rate of $\mathrm{v}$-th vehicle in $\%$ /year, $\mathrm{N}^{\mathrm{E}}(\mathrm{v})$ - the expected number of years of operation of $v$-th vehicle in years, $t_{\mathrm{PP}}^{\mathrm{O}}(\mathrm{v})$ - time of involvement of $v$-th vehicle in realization of transport task in days, $\mathrm{t}_{\mathrm{PP}}^{\mathrm{R}}(\mathrm{v})$ - the average time of involvement of $\mathrm{v}$-th vehicle in days/year.

Including wear cost as a part of task realization cost should take into account so-called balanced depreciation of 
vehicles, which stems from the Accounting Act [19]. Inclusion of tax depreciation in this regard (calculated in accordance with tax law) is a common mistake. In the light of the accounting regulations value of the vehicle breaks down on its lifespan and its residual value must be taken into account (after the period of its operation in the company), so the cost of vehicle wear is given by formula:

$$
\mathrm{K}_{\mathrm{A}}^{\mathrm{Z}}(\mathrm{v})=\left[\mathrm{W}_{\mathrm{P}}(\mathrm{v})-\mathrm{W}_{\mathrm{K}}(\mathrm{v})\right] \cdot \frac{\mathrm{t}_{\mathrm{PP}}^{\mathrm{O}}(\mathrm{v})}{\mathrm{N}^{\mathrm{E}}(\mathrm{v}) \cdot \mathrm{t}_{\mathrm{PP}}^{\mathrm{R}}(\mathrm{v})}(\mathrm{PLN})(2)
$$

where: $K_{A}^{Z}(v)$ - wear cost of $v$-th vehicle per transport task in PLN, $\mathrm{W}_{\mathrm{K}}(\mathrm{v})$ - residual value (net value) of $\mathrm{v}$-th vehicle in PLN, other symbols like in formula (1).

The costs of periodic technical inspection and insurance of vehicles result from the type of vehicles, their age and mileage. They are counted per task analogously to the cost of vehicle wear.

In case of taxes on means of transport in particular territorial units (municipalities) some significant differences in the classification of vehicles and rates may occur. According to the art. 10 of the Act on Local Taxes and Fees [17] these taxes may be dependent on:

- type of vehicle,

- permissible gross vehicle weight,

- number of axles,

- type of suspension,

- impact of the vehicle on the environment,

- year of manufacture,

- number of seats.

However, the last three criteria may be used only for vehicles with a GVW less than 12 tones and buses. It should be noted that individual municipalities often omit these criteria or use them in a very limited extent (ie. only two criteria are used: Euro II emission standard or higher and Euro I standard or lower). An example of good practice in this area is municipality Wejherowo where large differences in rates of tax on means of transport are implemented also because of Euro standards (Table 1). As can be seen in table in Wejherowo in most cases vehicles meeting Euro standard $\mathrm{V}$ or higher are burdened with approximately twice lower tax than vehicles meeting Euro II, III or IV standard.

Table 1. The rates of tax on means of transport in force in Wejherowo (PLN/year) [16]

\begin{tabular}{|l|c|c|c|c|}
\hline \multirow{2}{*}{ Type of vehicle } & \multirow{2}{*}{$\begin{array}{c}\text { GVW (t) or } \\
\text { the number of } \\
\text { seats }\end{array}$} & \multicolumn{3}{|c|}{ Euro standard } \\
\cline { 3 - 5 } & $(3.5-5.5]$ & 780 & 740 & 375 \\
\cline { 2 - 5 } & $(5.5-9.0]$ & 1320 & 1250 & 625 \\
\cline { 2 - 5 } & $(9.0-12)$ & 1570 & 1550 & 770 \\
\hline Rruck $\begin{array}{l}\text { Road tractor and } \\
\text { ballast tractor }\end{array}$ & {$[3.5-12)$} & 1780 & 1730 & 860 \\
\hline \multirow{2}{*}{$\begin{array}{l}\text { Trailer and } \\
\text { semi-trailer }\end{array}$} & {$[7.0-12)$} & 1580 & 1580 & 1580 \\
\hline Bus (coach) & up to 29 seats & 1830 & 1780 & 900 \\
\cline { 2 - 5 } & from 30 seats & 2320 & 2280 & 1150 \\
\hline
\end{tabular}

In Poland periodic tolls on national roads have been abolished from 1 July 2011. From that date one-time charges for the use of selected sections of national road network were introduced. In the ending phase of duration validity recurring charges were conditioned (excluding the period of validity) by the type of vehicle, the GVW and emissions standards.

\section{Variable costs in road transport in correlation with used vehicles}

In line with previous considerations, the variable costs dependent on the type of vehicle include the costs of:

- fuel consumption,

- tire wear,

- technical services and repairs,

- environmental fees,

- one-time charges for the use of transport infrastructure.

Costs of fuel consumption result from type of fuel and unit consumption, vehicle load, refuel strategies and local prices. In case of transport over long distances the capacity of fuel tank is very important. In fact it determines the choice of refuelling stations with significant differences in the price of fuel in individual countries or their regions. For example, the difference between the price of diesel in the UK and in Kosovo is about $60 \%$ [7]. Remembering that approximately $30-40 \%$ of the total cost is fuel, the potential savings are about $18-24 \%$ difference in total costs.

Costs of tire wear, maintenance and replacement of other consumables are about $10 \%$ of total transport costs. Their amount stems from a kind of used consumables and parts and distances travelled by the vehicle.

Environmental charges and one-time charges for the use of transport infrastructure, in contrast to described above variable costs, are highly dependent on the vehicle emission standard. Environmental fees are also a function of the type of fuel and type of vehicle. In addition, it is important that environmental fees are not paid if annual amount does not exceed 800 PLN or higher set by the Marshal of the province [20].

Taking into account the environmental regulations the ecological fee is given by formula:

$$
K_{S}^{Z}(v)=\frac{Z_{£}(v) \cdot L_{\text {Ł }}+Z_{P}(v) \cdot L_{P}}{100} \cdot \frac{\rho(v) \cdot S_{P}(v)}{1000}(P L N)
$$

where: $K_{S}^{Z}(v)$ - cost of using the environment by $v$-th vehicle during realization of transport task in PLN, $z_{t}(v)-$ average fuel consumption when driving with loads for $\mathrm{v}$-th vehicle in $\mathrm{dm}^{3} / 100 \mathrm{~km}$ or in $\mathrm{m}^{3} / 100 \mathrm{~km}, \mathrm{~L}_{\ell}$ - the distance travelled with load in $\mathrm{km}, \mathrm{z}_{\mathrm{p}}(\mathrm{v})$ - average fuel consumption when driving without loads for $\mathrm{v}$-th vehicle in $\mathrm{dm}^{3} / 100 \mathrm{~km}$ or in $\mathrm{m}^{3} / 100 \mathrm{~km}, \mathrm{~L}_{\mathrm{P}}$ - distance travelled without load per transport task in $\mathrm{km}, \rho(\mathrm{v})$ - density of the fuel used by engine of the $\mathrm{v}$-th vehicle in $\mathrm{kg} / \mathrm{dm}^{3}$ or in $\mathrm{kg} / \mathrm{m}^{3}, \mathrm{~S}_{\mathrm{p}}(\mathrm{v})$ - unit rate of fee for gases released into the environment produced through fuel combustion in the engine of v-th vehicle in PLN/Mg.

Unit rate of fee for gases released into the environment is strongly dependent on the vehicle emission standards. 
For example, for diesel-powered vehicles with a GVW over 3.5 tones and Euro V standard it is equal to $6.04 \mathrm{PLN} / \mathrm{Mg}$, while with Euro I standards it is more than four times higher (20.96). For trucks that do not meet the Euro I standard environmental fee is up to $50.00 \mathrm{PLN} / \mathrm{Mg}$ [13]. However, the share of the costs of using the environment in total costs is usually marginal.

Quite a serious group of costs are now one-time charges for the use of transport infrastructure. In long distance transport their participation exceeds $10 \%$ of the total transport costs. What is extremely important tolls are determined in relation to vehicle emission standard as well as its type and possibly the number of axles. As example the toll rates in Electronic Toll Collection Systems in Germany and Poland are presented (Tab. 2 and 3 ).

Table 2. Tolls for travelling $1 \mathrm{~km}$ of motorway in Germany (EUR/km) [5]

\begin{tabular}{|l|c|c|c|c|c|c|}
\hline \multirow{2}{*}{$\begin{array}{l}\text { Number } \\
\text { of axles }\end{array}$} & \multicolumn{7}{|c|}{ Category of vehicle (Euro standard) } \\
\cline { 2 - 7 } & $\begin{array}{c}\mathrm{A} \\
\text { (VI) }\end{array}$ & $\begin{array}{c}\mathrm{B}(\mathrm{V}, \\
\text { EEV 1) }\end{array}$ & $\begin{array}{c}\mathrm{C}(\mathrm{IV}, \\
\left.\mathrm{II}_{\mathrm{PMK}}\right)\end{array}$ & $\begin{array}{c}\mathrm{D}(\mathrm{III}, \\
\mathrm{II}_{\mathrm{PMK}}\end{array}$ & $\begin{array}{c}\mathrm{E} \\
\text { (II) }\end{array}$ & $\begin{array}{c}\mathrm{F} \\
\text { (I, 0) }\end{array}$ \\
\hline up to 3 & 0.125 & 0.146 & 0.157 & 0.188 & 0.198 & 0.208 \\
\hline 4 and more & 0.131 & 0.152 & 0.163 & 0.194 & 0.204 & 0.214 \\
\hline $\begin{array}{l}\text { PMK - category of particulate matter reduction is the standard of } \\
\text { additional equipment to educe particulate matters emissions. }\end{array}$ \\
\hline
\end{tabular}

As it results from Table 2 tolls in Germany are less than $40 \%$ lower for vehicles meeting the highest emission standards than for vehicles with lowest Euro standards.

Table 3. Tolls for travelling $1 \mathrm{~km}$ of national road in Poland (PLN/km) [14] \begin{tabular}{|l|l}
\hline Car of combination & Euro standard \\
\hline
\end{tabular} of vehicles

\begin{tabular}{|c|c|c|c|c|c|}
\hline Type & GVW (t) & $\max$. II & III & IV & $\min . \mathrm{V}$ \\
\hline \multicolumn{6}{|c|}{ Motorways and expressways } \\
\hline Bus & any & 0.40 & 0.35 & 0.28 & 0.20 \\
\hline \multirow{2}{*}{$\begin{array}{l}\text { Other } \\
\text { than bus }\end{array}$} & $(3.5-12)$ & 0.40 & 0.35 & 0.28 & 0.20 \\
\hline & from 12 & 0.53 & 0.46 & 0.37 & 0.27 \\
\hline \multicolumn{6}{|c|}{ Other roads covered by fees } \\
\hline Bus & any & 0.32 & 0.28 & 0.22 & 0.16 \\
\hline \multirow{2}{*}{$\begin{array}{l}\text { Other } \\
\text { than bus }\end{array}$} & $(3.5-12)$ & 0.32 & 0.28 & 0.22 & 0.16 \\
\hline & from 12 & 0.42 & 0.37 & 0.29 & 0.21 \\
\hline
\end{tabular}

In Poland the differences are about 50\%. Thus, under a $10 \%$ share of road use cost in total costs, the impact of emissions standards on total costs of transport in this aspect can be $5 \%$ or more.

Table 5. Simplified timetable of transport realization

\begin{tabular}{|c|c|c|c|c|c|c|c|c|}
\hline \multirow[t]{2}{*}{ Description of activities } & \multicolumn{3}{|c|}{ Duration time (h:min) } & \multirow[t]{2}{*}{ Country } & \multirow[t]{2}{*}{ Day } & \multicolumn{3}{|c|}{ Time (h:min) } \\
\hline & Time & From & To & & & Drive & Work & Duty \\
\hline Vehicle maintenance & $0: 30$ & 10:00 & $10: 30$ & PL & Mon & & $0: 30$ & \\
\hline Loading & $1: 40$ & $10: 30$ & $12: 10$ & PL & Mon & & $1: 40$ & \\
\hline Drive & $3: 20$ & 12:10 & $15: 30$ & PL & Mon & $3: 20$ & $3: 20$ & \\
\hline Break & $0: 45$ & 15:30 & $16: 15$ & PL & Mon & & $0: 15$ & $0: 30$ \\
\hline Drive & $2: 36$ & $16: 15$ & $18: 51$ & PL & Mon & $2: 36$ & $2: 36$ & \\
\hline Drive & $1: 54$ & $18: 51$ & $20: 45$ & $\mathrm{DE}$ & Mon & $1: 54$ & $1: 54$ & \\
\hline Break & $0: 45$ & $20: 45$ & $21: 30$ & $\mathrm{DE}$ & Mon & & & $0: 45$ \\
\hline Drive & $2: 00$ & $21: 30$ & $23: 30$ & $\mathrm{DE}$ & Mon & $2: 00$ & $2: 00$ & \\
\hline Rest & 9:05 & $23: 30$ & $8: 35$ & $\mathrm{DE}$ & Tue & & & \\
\hline \multicolumn{6}{|l|}{ Summary of the day } & 9:50 & $12: 15$ & $1: 15$ \\
\hline Vehicle maintenance & $0: 10$ & $8: 35$ & $8: 45$ & $\mathrm{DE}$ & Tue & & $0: 10$ & \\
\hline Drive & $0: 59$ & $8: 45$ & $9: 44$ & $\mathrm{DE}$ & Tue & $0: 59$ & $0: 59$ & \\
\hline Loading & $3: 20$ & $9: 44$ & 13:04 & $\mathrm{DE}$ & Tue & & $3: 20$ & \\
\hline Drive & $1: 00$ & 13:04 & $14: 04$ & $\mathrm{DE}$ & Tue & 1:00 & $1: 00$ & \\
\hline Break & $0: 45$ & 14:04 & $14: 49$ & $\mathrm{DE}$ & Tue & & $0: 15$ & $0: 30$ \\
\hline Drive & $3: 53$ & $14: 49$ & $18: 42$ & $\mathrm{DE}$ & Tue & $3: 53$ & $3: 53$ & \\
\hline Drive & $0: 20$ & $18: 42$ & 19:02 & PL & Tue & $0: 20$ & $0: 20$ & \\
\hline Break & $0: 45$ & 19:02 & 19:47 & PL & Tue & & & $0: 45$ \\
\hline Drive & $3: 40$ & 19:47 & $23: 27$ & PL & Tue & 3:40 & $3: 40$ & \\
\hline Rest & 9:05 & $23: 27$ & $8: 32$ & PL & Wed & & & \\
\hline \multicolumn{6}{|l|}{ Summary of the day } & $9: 52$ & $13: 57$ & $1: 15$ \\
\hline Vehicle maintenance & $0: 10$ & $8: 32$ & $8: 42$ & PL & Wed & & $0: 10$ & \\
\hline Drive & $1: 56$ & $8: 42$ & $10: 38$ & PL & Wed & $1: 56$ & $1: 56$ & \\
\hline Loading & $1: 40$ & $10: 38$ & $12: 18$ & PL & Wed & & $1: 40$ & \\
\hline Vehicle maintenance & $0: 20$ & $12: 18$ & $12: 38$ & PL & Wed & & $0: 20$ & \\
\hline \multicolumn{6}{|l|}{ Summary of the day } & $1: 56$ & $4: 06$ & $0: 00$ \\
\hline \multicolumn{6}{|l|}{ Summary of the transport cycle } & $21: 38$ & $29: 58$ & $2: 30$ \\
\hline
\end{tabular}




\section{Case study}

The discussion about the impact of the type of vehicles and their technical parameters on the cost of transport presented in the paper is exemplified for a single-driver transport in Mszczonów (PL) - Hamburg (DE) relation. Examined variants were based on vehicles meeting Euro III, IV, V and VI emission standards. These vehicles also differ in year of production, initial and residual value, and expected service life (Tab. 4). It was assumed that vehicles meeting Euro V and VI standard were purchased as new and will be operated for 8 years, while those meeting Euro III and IV standards were bought used and will be operated for 3 years.

Table 4. Some features of compared sets of vehicles

\begin{tabular}{|l|c|c|c|c|c|}
\hline No. & $\begin{array}{c}\text { Euro } \\
\text { stand. }\end{array}$ & $\begin{array}{c}\text { Year of } \\
\text { prod. }\end{array}$ & $\begin{array}{c}\text { Initial } \\
\text { value } \\
{[\text { PLN }]}\end{array}$ & $\begin{array}{c}\text { Residual } \\
\text { value } \\
{[\text { PLN }]}\end{array}$ & $\begin{array}{c}\text { Unit fuel } \\
\text { consumption } \\
{\left[\mathrm{dm}^{3} / 100 \mathrm{~km}\right]}\end{array}$ \\
\hline 1 & III & 2004 & 104156 & 89301 & 34.0 \\
\hline 2 & IV & 2006 & 116189 & 99618 & 33.0 \\
\hline 3 & V & 2010 & 359057 & 129129 & 31.0 \\
\hline 4 & VI & 2015 & 367348 & 132111 & 29.0 \\
\hline
\end{tabular}

All compared vehicles are sets of tractors coupled with semi-trailers of 40 tons of GVW. It is assumed that the tractor unit has two axles and the trailer has 3 axles. All vehicles have air suspension, are powered by diesel engines and are registered in the municipality of Mszczonów.

Simplified timetable for transport cycle in relation Mszczonów (PL) - Hamburg (DE) for one driver is presented in
Table 5. It is assumed that driver has a contract of employment and work under equivalent work time system. The night time is set from 0:00 to 4:00 and is used for the purposes of setting working time.

On the base of presented schedule it was agreed that the driver performing the transportation was working for 26 hours and 38 minutes within a normal work time and also generated 2 hours and 53 minutes of overtime paid in 100\%, and 27 minutes of overtime paid in 50\%. At night (from 23:00 to 7:00 - period adopted for the purposes of determining salary), driver works for 57 minutes and stays on duty for 2.5 hours.

Additionally the driver performing business trip should receive compensation for 1.5 domestic diets, 1 foreign diet and flat rate for one night spent in the country and for a one night spent in Germany.

Taking into account described assumptions and tax rates and fees applicable for 2015, as well as average fuel cost from 20 May 2015, the analysis of transport costs for different vehicles was performed. Results are given in Table 6 .

As it results from Table 6, using vehicles that meet the highest emission standards is cost-effective in examined transport relation. Total transport cost is lower by $6.5 \%$ than in case of using vehicles meeting the Euro III emission standard. Benefits of using vehicles with Euro IV and Euro V standards are lower (Fig. 3).

It should be noted that lower transport costs for vehicles with lower age are mainly due to lower utilization of consumable materials. The benefits from lower tolls and lower environmental fees would not get the same conclusions.

Table 6. Comparison of the cost of servicing examined relation by different vehicles (PLN)

\begin{tabular}{|c|c|c|c|c|}
\hline Type of costs & $\begin{array}{l}\text { Vehicle } 1 \\
\text { (Euro III) }\end{array}$ & $\begin{array}{l}\text { Vehicle } 2 \\
\text { (Euro IV) }\end{array}$ & $\begin{array}{l}\text { Vehicle } 3 \\
\text { (Euro V) }\end{array}$ & $\begin{array}{l}\text { Vehicle } 4 \\
\text { (Euro VI) }\end{array}$ \\
\hline Costs related to vehicle & 3811.18 & 3629.83 & 3733.96 & 3476.11 \\
\hline Financing vehicles & 34.45 & 38.43 & 94.25 & 96.43 \\
\hline Wear of vehicles & 41,59 & 46,40 & 272,41 & 247.00 \\
\hline Periodic technical inspections & 33.60 & 33.60 & 25.20 & 16.80 \\
\hline Insurance of vehicles & 33.25 & 37.09 & 82.21 & 84.11 \\
\hline Tax on means of transport & 34.94 & 34.94 & 34.94 & 34.94 \\
\hline Fuel consumption & 2127.05 & 2064.49 & 1939.37 & 1814.25 \\
\hline Wear of tyres & 212.70 & 206.45 & 193.94 & 181.42 \\
\hline Technical services and repairs & 425.41 & 412.90 & 387.87 & 362.85 \\
\hline Ecological fees & 5.62 & 3.96 & 2.58 & 2.42 \\
\hline Road fees & 862.57 & 751.58 & 701.18 & 635.89 \\
\hline German motorways (A12, A24) & 603.14 & 506.76 & 472.56 & 407.28 \\
\hline Polish motorway covered by the concession (A2) & 184.85 & 184.85 & 184.85 & 184.85 \\
\hline Polish national roads covered by ESPO & 74.58 & 59.97 & 43.77 & 43.77 \\
\hline Driver labour costs & 1365.95 & 1365.95 & 1365.95 & 1365.95 \\
\hline Base salary & 760.95 & 760.95 & 760.95 & 760.95 \\
\hline Overtime & 124.40 & 124.40 & 124.40 & 124.40 \\
\hline Night hours & 2.26 & 2.26 & 2.26 & 2.26 \\
\hline Duty & 29,76 & 29.76 & 29.76 & 29.76 \\
\hline Domestic and foreign diets & 248.12 & 248.12 & 248.12 & 248.12 \\
\hline Domestic and foreign accommodations & 200.45 & 200.45 & 200.45 & 200.45 \\
\hline Total costs & 5177.13 & 4995.78 & 5099.91 & 4842.06 \\
\hline
\end{tabular}




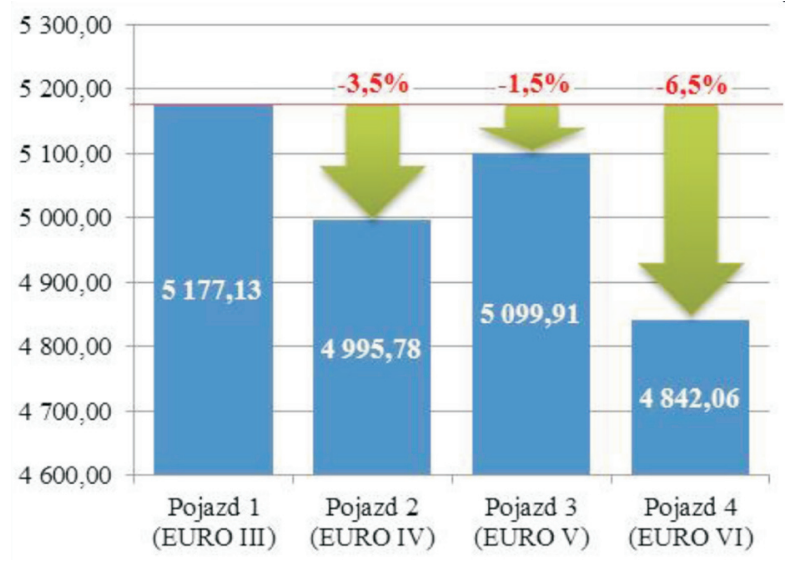

Fig. 3. Comparison of the cost of transport realized by considered vehicles

\section{Summary}

The discussion conducted in the paper concludes dependences between costs of transport, types of vehicles and their technical parameters. As it has been noted, part of fixed and variable costs is greatly dependent on the type of vehicle, its value, and its certain features like type of suspension or emission standards.

The significant relationship between charges for the use of infrastructure and environmental charges reflecting vehicle emissions standards is not sufficient to promote green attitudes in road transport. Only taking into account the wear of older vehicles meeting lower emission standards, as well as their higher operating costs convinces that the use of modern low-emission vehicles is more profitable.

Taking into account above considerations it should be noted that currently there are no sufficient economic mechanisms to support environmentally friendly transportation of goods.

\section{Bibliography}

[1] Ambroziak T., Jacyna M., Gołębiowski P., Wasiak M., Żak J. Wpływ rozłożenia potoku ruchu w sieci transportowej na poziom emisji $\mathrm{CO}_{2}$ przez środki transportu. Prace Naukowe Politechniki Warszawskiej, Transport, 97, 2013, 9-18.

[2] Bąk M. Koszty i opłaty w transporcie. Wydawnictwo Uniwersytetu Gdańskiego, Gdańsk 2009.

[3] Bentkowska-Senator K., Kordel Z., Waśkiewicz J. Koszty w transporcie samochodowym. Instytut Transportu Samochodowego, Warszawa 2011.

[4] Bogdanowicz S. Podatność. Teoria i zastosowanie w transporcie. Oficyna Wydawnicza Politechniki Warszawskiej, Warszawa 2012.

[5] Gesetz über die Erhebung von streckenbezogenen Gebühren für die Benutzung von Bundesautobahnen und Bundesstraßen (Bundesfernstraßenmautgesetz - BFStrMG).

Prof. Marianna Jacyna, PhD - Professor in the Faculty of Transport at Warsaw University of Technology.

Prof. dr hab. inż Marianna Jacyna - profesor zwyczajny na Wydziale Transportu Politechniki Warszawskiej.

e-mail:maja@wt.pw.edu.pl

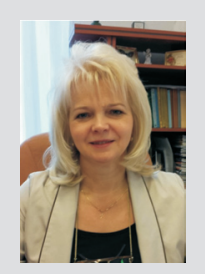

[6] Gołębiowski P., Jachimowski R., Lewczuk K., Szczepański E., Wasiak M. Uwarunkowania prawne kształtowania proekologicznego systemu transportowego. Prace Naukowe Transport, z. 97, Oficyna Wydawnicza Politechniki Warszawskiej, Warszawa 2013.

[7] http://www.e-petrol.pl/notowania/rynek-krajowy/ceny-stacjepaliw [dostęp: 24.05.2015].

[8] Jacyna M. Modelowanie i ocena systemów transportowych. Wydawnictwo Politechniki Warszawskiej, Warszawa 2009.

[9] Jacyna M., Lewczuk K., Kłodawski M., Jachimowski R., Sivets O., Gołębiowski P., Wasiak M. Opłaty drogowe w funkcji klasy emisji spalin pojazdów w Polsce na tle wybranych krajów Unii Europejskiej. Logistyka, 4, 2014, 2097-2106.

[10] Jacyna M., Wasiak M. (red.) Simulation model to support designing a sustainable national transport system. Index Copernicus International, Warsaw 2014.

[11] Janic M. Modelling the full costs of an intermodal and road freight transport network. Transportation Research, Part D, Elsevier, 12, 2007, 33-44.

[12] Lissowska E. (red.) Technologia procesów przewozowych w transporcie samochodowym. Wydawnictwa Komunikacji i Łączności, Warszawa 1975.

[13] Obwieszczenie Ministra Środowiska z dnia 14 sierpnia 2014 r. w sprawie wysokości stawek opłat za korzystanie ze środowiska na rok 2015.

[14] Rozporządzenie Rady Ministrów z dnia 22 marca 2011 r. w sprawie dróg krajowych lub ich odcinków, na których pobiera się opłatę elektroniczną, oraz wysokości stawek opłaty elektronicznej.

[15] Sivets O., Jacyna M. Wielkość kosztów transportu w zależności od norm emisji spalin pojazdu. Prace Naukowe Transport, z. 101, Oficyna Wydawnicza Politechniki Warszawskiej, Warszawa 2014.

[16] Uchwała NrVIk/XXIII/269/2012 Rady Miasta Wejherowa z dnia 9 października 2012 r. w sprawie określenia stawek podatku od środków transportowych (obowiązująca również w 2015 r.).

[17] Ustawa z dnia 12 stycznia $1991 \mathrm{r}$. o podatkach i opłatach lokalnych (DzU 1991, nr 9, poz. 31, ze zm.).

[18] Ustawa z dnia 15 lutego 1992 r. o podatku dochodowym od osób prawnych (DzU 1992, nr 21, poz. 86, ze zm.).

[19] Ustawa z dnia 29 września 1994 r. o rachunkowości (DzU 1994, nr 121, poz. 591, ze zm.).

[20] Ustawa z dnia 27 kwietnia 2001 r. Prawo ochrony środowiska (DzU 2001, nr 62, poz. 627, ze zm.).

[21] Wasiak M.: Modelowanie przepływu ładunków w zastosowaniu do wyznaczania potencjału systemów logistycznych. Prace Naukowe Transport, z. 79, Oficyna Wydawnicza Politechniki Warszawskiej, Warszawa 2011.

[22] Wasiak M. Uwarunkowania projektowania długodystansowych przewozów ładunków transportem samochodowym. Prace Naukowe Transport, z. 97, Oficyna Wydawnicza Politechniki Warszawskiej, Warszawa 2013.

[23] Wasiak M. Uwarunkowania stosowania modelu systemu logistycznego do optymalizacji potencjału systemów przewozowych. Logistyka, 4, 2012, 757-768.

Mariusz Wasiak, DSc., DEng. - Professor in the Faculty of Transport at Warsaw University of Technology.

Dr hab. inż. Mariusz Wasiak, prof. PW-profesor nadzwyczajny na Wydziale Transportu Politechniki Warszawskiej.

e-mail: mwa@wt.pw.edu.pl 